\title{
Projects of Life of People of The Muslim Faith Released from Russian Prisons
}

\author{
Dina Tanatova \\ Russian State Social University, 4, V.Pika St. Moscow, Russia \\ Irina Leskova \\ Russian State Social University, 4, V.Pika St. Moscow, Russia \\ Tatyana Yudina* \\ Russian State Social University, 4, V.Pika St. Moscow, Russia
}

\begin{abstract}
Here we study the projects of life of Muslims who have served their sentences for fraud and other crimes and returned from Russian prisons in the past three years. There was a hypothesis that the Muslim culture had significant impact on the processes of resocialization and social adaptation after the release from prison. However, it was not confirmed: a high percentage of repetitions of crime were revealed among previously convicted Muslims, as well as the inefficient use of religious resources as a worldview and humanitarian foundation. The theory of socialization (T.Parsons) and the theory of identity (G.Mead) were used as a methodology for empirical study.
\end{abstract}

Keywords: projects of life, resocialization, social adaptation, Muslims, former prisoners.

DOI: $10.7176 /$ RHSS/11-11-11

Publication date:June $30^{\text {th }} 2021$

\section{Introduction}

For a long period of time, the processes of social adaptation and resocialization of people released from prison, including those associated with the projects of life, remain the sever social challenge and do not cease to be the subject of various sociological studies (Tanatova et al., 2020).

In ordinary life, people live unforced, make personal plans for creating their own family and career, have hobbies. They may have children, build relationships with parents, relatives, and colleagues, have stable job that they like or do not like, loyal pet, fitness twice a week, once a month sauna and fishing, where they meet their friends, etc. In the ordinary format of his pastime, a person does not think that somewhere nearby there is a jail or prison settlement, that there is a completely different life, different social norms and rules. Once in the prison, a person usually gets lost, he needs to re-learn dos and don'ts in the environment in which he found himself.

Resocialization and social adaptation of representatives of Muslim culture who have served their sentences is a complicated process. Undoubtedly, the life of each of the convicted Muslims can be conditionally divided into stages: 'before the term of punishment', 'punishment / correction', 'freedom'. These periods cannot be merged, a person lives three completely different lives, and therefore he has to build a system of life principles and values several times.

Commitment to live a normal life in freedom depends on how many the life-meaning orientations and interests of the individual have undergone deformation after being in social isolation, according to the nature of his character, prone to crime. A prison, being an institution in which persons are placed and kept in solitary or mass cells, previously sentenced by a court to a criminal punishment in the form of imprisonment, is a separate, guarded, and functionally adapted group of buildings that guarantees the increased isolation of criminals from the society and increased supervision of their behavior. In the usual sense, our citizens basically mean of prisons almost all penitentiary institutions - pretrial detention centers, educational and correctional facilities, and jails where people are kept in isolation. The reputation of a "former prisoner" complicates greatly the tasks of finding a job, social networking, building a personal life, and tests a person for stress resistance.

\section{Discussion}

After the prison sentence, Muslims, like other set at liberty people, have basically two ways: to commit a new crime and return to the previous conditions of life, or to earn an honest livelihood and make up for lost time and opportunities, continuing personal development in freedom. They have to break the value system existing in prisons and adapt to the new world of freedom.

The goal of resocialization of convicted persons is understood as a change in norms and values, behavior models of a resocialized person, the achievement of positive social experience and subjectivity to realize the possibility of its productive life in society (Tanatova et al., 2020).

Resocialization turns out to be a difficult, sometimes cruel process. Prejudice and misunderstandings can 
arise both in the family and when applying for a job. Even if a person was earlier well regarded and had no complaints from the employer, but was prosecuted, it is almost impossible for him to get a job, not to mention a job with high earnings. Former friends and colleagues will avoid and be frightened by both the former prisoner himself and his possible social network. Such people can't count on support from relatives either: constant suspicion and fear in communication, lack of compassion and any possible help can break a person; there is a danger that he will commit a crime again and will be ready to return to an environment where he will not be constantly suspected and pushed away. This problem exists, and in this case it is not the fault of the former prisoner, but of the stereotypical behavior in society.

In the framework of an evolving national dialogue, the causes of recidivism are being explored in many publications about the penitentiary system (Sentencing Project, 2019), (Scott, 2013).

\section{Previous study}

Convicted Muslims can be conditionally classified into two numerically unequal categories: the majority serving sentences for personal crimes and the minority serving sentences for crimes of terrorist and extremist natures. These two categories differ significantly in degree of religious conviction and psychological types.

Studying the secondary data of the expert opinion of the staff of penitentiary facility shows that the situation in the field of religious self-comprehension of convicts is changing rapidly, and this situation is alarming: along with a decrease in the number of prisoners sentenced to imprisonment, there is an increase in the number of Muslims among convicts. Often convicts adopt a religious worldview while in prison (Sysoev, 2014).

Repetition of crime among those sentenced to punishments and other measures not related to imprisonment are committed under the influence of, among other things, previous crimes (Drozdov, 2019). The spread of radical forms of Islam among Muslims remains a significant problem (Suleimanov, 2015).

In this connection, it can be concluded that the high percentage of recidivism among previously convicted Muslims is associated, among other things, with the ineffective use of the resources of religion as an ideological and humanitarian basis.

\section{Methodology and methods}

The theory of socialization (T.Parsons) and the theory of identity (G.Mead) were used as a methodology for the empirical study. Social institutions define roles for members of the society, which the latter master in the course of socialization or adaptation as the stage of socialization. However, fewer than all adopt prescribed roles and abide generally accepted rules. Sociological methods were used, in particular, focus groups with former convicts and in-depth interviews with penitentiary facility staff. The first focus group $(\mathrm{N}=12)$ included Muslims practicing Islam, with secular manners, and ideas about life quite close to European traditions. The second group $(\mathrm{N}=9)$ included Muslims who practiced Islam and impeccably complied with all the requirements of the Islamic religion.

In-depth interviews $(\mathrm{N}=5)$ were conducted with penitentiary facility staff in order to identify personal attitudes, the potential of social functions in the process of monitoring prisoners who were in penitentiary facilities just before their release.

\section{Results}

The study have shown that the first group of respondents find excuses in a turn of events, in particular in poverty and insuperable difficulties that pushed them to fraudulent actions in their past life. The second group of respondents are deeply religious Muslims, brought up in the best traditions, where religious canons are passed down through generations. They refer to fate and the situation when '... everything is the will of the Almighty'. Both groups believe that a lot of time and effort is needed for the complete adaptation to society.

Values and life purpose. The sphere of the value and purpose acts as a fundamental construct after the prison life of convicts. Without its analysis, it is difficult to predict the determinants of the actions and behavior of the person (Sobolev, 2019).

The results of the study have shown that more than half of the respondents see the value and meaning of their life in family and children. Most of the respondents emphasized that it is children and loved ones who are the only thing that they have good in their life and that gives them the strength not to stumble again.

The values and meaning of life is associated with the desire to live a generally problem-free life filled with positive events. The majority of respondents indicated that positive thoughts help them to distract from the real situation and find the strength to survive the failures associated with the process of resocialization in society.

A third of the respondents noted that it is difficult for them to think about their future and expectations. A quarter of the respondents admitted that they do not feel the support they counted on after their release, and unfulfilled hopes turned into an illusion and wasteful dreams. For those released at a more mature age, focus and reflection on events and surroundings from the past that 'do not let go' are characteristic.

Employment. For the Muslims released from prisons, the problem of upcoming employment as one of the 
fundamental tools for effective resocialization and social adaptation is very acute and urgent. Much depends on potential employers, since the relationship between them and the former prisoner as a worker must be based on respect for human rights: the right to work and the right of mutual respect. It should be emphasized that many who have been released from prison after imprisonment commit crimes again precisely because they cannot find work, as well as a worthy application for themselves in the host society.

With regard to Muslim prisoners, not only former inmates who have successfully came through resocialization and social adaptation, or the administration of prison settlements, together with other social structures, organizing job fairs can help to find a job. Various forums are being actively created on websites, including social networks, where advertisements for vacancies 'Work for Muslims' and for individual 'brothers and sisters' are published. In the published vacancies, potential workers are allowed to perform Namaz and dress in accordance with religious and traditional prescriptions, which is of particular importance to Muslims. At the same time, Muslims distinguish between "halal" and "haraam" work. Halal work is one that pleases Allah and does not prevent adhering to Islamic practices. Haraam work, otherwise, does not meet the basic requirements of Islam or prevents adhering to Islamic practices. Such support in employment makes it possible to achieve a certain degree of efficiency in the resocialization and social adaptation of former Muslim prisoners, especially those who came to religion not so long ago and possibly directly in places of detention.

An example is the site muslimboard.ru. The largest number of vacancies is presented in such areas as catering, construction, apartment renovation, and trade. At the same time, most of the vacancies are offered in large cities and metropolitan areas. Thus, most opportunities for effective resocialization and social adaptation of Muslim prisoners and for the implementation of their life plans are in large cities.

Difficulties with employment of convicts after release from correctional institutions can be summarized as follows:

1. High likelihood of convicts getting "prisoner stigma" when trying to find a job and establish productive social networking at their place of residence after release;

2. Legal restrictions that prevent applying for some jobs;

3. Employer deception: refusal to sign an official labor contract, non-payment of salaries - all this pushes some of the former prisoners to return to the path of committing new crimes.

Other problems that hinder the implementation of the life plans of Muslims who have returned from detention: some of the convicts have no permanent residency, as well as the lack of proper protection from law enforcement agencies and the judiciary.

According to the focus-group results, the projects of life of both groups are close. They are making efforts to restore their status, financial situation, and social recognition. Since it takes considerable time to achieve these goals, they usually rely on various communities and clans that form around the mosque.

In-depth interviews with the staff of detention centers were aimed at clarifying the life strategies of Muslims after their release. Experts pointed out the need to work with this category of citizens, aimed at the correction of the sense-bearing deformations of the subjective pattern of life, clarifying the system of life goals, expectations and desires, expanding and enriching the meaning of life with new sources. The importance of preparing and testing correctional programs for the development of axiological regulation of the life path of former convicts was especially emphasized.

It was especially emphasized that a significant factor influencing the process of resocialization of a former prisoner is his family's lifestyle. The success of adaptation depends on socio-psychological factors, including the family microclimate: quarrels, insults, or cases of physical violence reduce the success of adaptation to negative results.

In general, the process of resocialization is adversely affected by such circumstances as the presence of single-parent families, as well as the presence of so-called dysfunctional families characterized by a low level of culture of relations, attitudes towards illegal behavior, and the presence of members prone to drinking alcohol. In addition, the effectiveness of family support depends on intra-family relations, the distribution of roles in the family before and after imprisonment (Finaeva, 2012).

Mentality and urban environment. A significant share of representatives of Muslim culture who have been released from prison, which are becoming a part of the population of large cities, consists of those who came from rural areas, or from small towns, i.e. with a peasant mentality. Without getting into details of the structure and other significant properties of the peasant mentality, we only note that today it seriously contradicts with the modern urban human environment. With regard to adaptation, resocialization and construction of life plans, it is manifested in the fact that both the urban family, which has largely lost the patriarchal character, and the territorial community in a modern big city have lost their former opportunities to influence the behavior of individual members of the community, the ability to exercise effective social control. New leverage has not been formed yet.

The urgency of the topic presented is due to the importance of religion for the Muslim population of large cities and megacities, as well as for the representatives of Muslim culture in general, which include both 
believers and those who is not an adherent of the Islamic faith, but whose personal formation was associated with the assimilation of the values characteristic of this religion. The growing public resonance of crimes committed by visiting representatives of Muslim culture can become a serious factor in the growth of general social tension in the social environment of large cities and megalopolises of Russia (Zyazin, 2020). At the same time, a significant part of those who violated the law, after their release, seek to link their future life with large cities with a population of over one million or with Russian megalopolises. Moreover, a considerable proportion of prisoners with a corresponding cultural identity serving sentences in correctional institutions, and, accordingly, those who are released over time are convicted not for the first time.

\section{Conclusion}

Having achieved their main goal and released to freedom, the freed persons may lose their value positions for self-determination and life guidelines that set meanings and value attitudes towards their further existence.

The readiness and desire of a convict to resume a law-abiding way of life in society is determined by the quality of his axiological attitudes. The main indicator of readiness for life in freedom can be the formation of positive orientations of the convict, which fit into the socio-cultural environment of the host community.

Russian Muslims who have come out of jail quite clearly see their projects of life. However, realizing their unattainability in a short time, they are often get involved in criminal activity again, using a criminal behavior model. At the same time, they interpret their religious ideas in excusatory intonation, referring to irresistible life circumstances.

A high percentage of recidivism among previously convicted Muslims is associated, among other things, with inefficient use of religious resources as a worldview and humanitarian foundation.

At the same time, for Muslims, a characteristic feature is general group belonging, and, as a result, mutual assistance. In this regard, it is necessary to stimulate a positive trend in the formation of social groups in which Muslims are members in order to counter the spread of radical extremist sentiments and create conditions for reducing the level of social tension in the Russian society.

\section{References}

Tanatova Dina K. (Kabdullinovna), Leskova Irina V. (Valeryevna) \& Yudina Tatyana N.(Nikolaevna), Women in the prison system. International symposium on gender and prison culture. projects of life of people of the muslim faith. released from Russian prisons. Ref.: 229M22020.

Tanatova D.K., Zyazin S.Yu., Leskova I.V. [The conceptual and terminological triad «socializationdesocialization-resocialization» and the circle of socio-cultural phenomena designated by these terms] World of Science. Series: Sociology, Philology, Cultural Studies, 2020, Vol. 11, No. 2. Available at: https://sfk-mn.ru/PDF/01SCSK220.pdf (in Russian). Sentencing Project (2019). Criminal justice facts. Retrieved from https:/www.sentencingproject.org/criminal-justice-facts/ (дата обращения 21.12.2020).

Scott R. (2013). Distinguishing radical teaching from merely having intense experiences while teaching in prison // The Radical Teacher. No95. 22-32. doi:10.5406/radicalteacher.95.0022.

Drozdov I.S. (2019), The structure of criminological Recidivism of persons convicted without imprisonment // Ugolovnaya yustitsia - Russian Journal of Criminal Law, 2019, 13, 126-132. DOI. 10.17223/23088451/13/25 (accessed Jan. 20, 2021).

Suleymanov R.V. (2015), Russkiye musulmane: klassifikatsiya grupp, problema radikalizma, otnosheniye k nim $\mathrm{v}$ Rossii (Russian Muslims: classification of groups, the problem of radicalism, attitudes towards them in Russia) // Musulmansky mir. No. 4. URL: https://cyberleninka.ru/article/n/russkie-musulmaneklassifikatsiya-grupp-problema-radikalizma-otnoshenie-k-nim-v-rossii (accessed Jan. 23, 2021) (In Russian).

Sysoev A.M. (2014) Characteristics of Islamic radicalization in prisons convicted of the Russian Federation // Chelovek: prestupleniye i nakazaniye. No. 1(84). URL: https://cyberleninka.ru/article/n/harakteristikaislamskoy-radikalizatsii-osuzhdennyh-v-ispravitelnyh-uchrezhdeniyah-rossiyskoy-federatsii (accessed: March 23, 2021). (In Russian).

Sobolev N.G. (2019). Characteristics of the value-semantic sphere of male convicts who committed a crime by negligence. World of Science. Pedagogy and psychology, [online] 6(7). Available at: https://mirnauki.com/PDF/33PSMN619.pdf (in Russian).

Finaeva A.G. (2012) Semeynyye strategii v strukture resotsializatsii zaklyuchennykh (Family strategies in the structure of prisoners' resocialization) // Izvestia of Saratov University. New Series. Series: Sociology. Politology. No. 3. URL: https://cyberleninka.ru/article/n/semeynye-strategii-v-strukture-resotsializatsiizaklyuchennyh (accessed: Jan. 20, 2021).

Zyazin S.Yu. (2020), Spetsifika resotsializatsii osvobodivshikhsya zaklyuchennykh-musul'man v megapolise: teoreticheskiye aspekty problemy (Specifics of Resocialization of Released Muslim Prisoners in the Metropolis: Theoretical Aspects of the Problem). Monograph. Moscow: Mir Nauki, 250 p. ISBN 978-5- 
6045532-5-1 (In Russian).

\section{Author: Dina Tanatova K. (Kabdullinovna)}

Russian State Social University, Moscow, Russia

Dean of the faculty of «Sociology»

Doctor of social Sciences, Professor

E-mail: dktanatova@mail.ru

Telephone +79104304984

ORCID: https://orcid.org/0000-0002-7924-2242

РИНЦ: https://elibrary.ru/author_profile.asp

Web of Science (Publons): https://publons.com/researcher/3176329/dina-tanatova/

SCOPUS: https:/www.scopus.com/authid/detail.uri?authorId=56748103100

Google the academy: https://scholar.google.com/citations?user=eytHQjQAAAAJ\&hl=ru\&oi=sra

\section{Co-Author: Irina Leskova V. (Valeryevna)}

Russian State Social University, Moscow, Russia

Professor of the Department of «Sociology»

Doctor of social Sciences, Professor

E-mail: leskova.i@yandex.ru

Telephone + 79055502708

ORCID: http://orcid.org/0000-0001-6083-6692

РИНЦ: https://www.elibrary.ru/author_profile.asp?id=510760

Web of Science (Publons): https://publons.com/researcher/3362856/

SCOPUS: http://www.scopus.com/authid/detail.url?authorId=56610215200

Google the academy: https://scholar.google.com/citations?user=BfYOFYMAAAAJ

\section{Co-Author: Tatyana Yudina N. (Nikolaevna)}

Russian State Social University, Moscow, Russia

Head of the Department of «Sociology»

Doctor of social Sciences, Professor

E-mail: ioudinatn@mail.ru

Telephone +79175437720

SPIN-код: 4150-5328

ORCID ID: https://orcid.org/0000-0001-7785-8601

ResearcherID: P-5028-2015

http://apps. webofknowledge.com/summary.do?product=WOS\&parentProduct $=$ WOS\&search mode $=$ GeneralSea rch\&qid=4\&SID=C2WO95hXxXO37FAsaKF\&colName=WOS\&\&page $=1 \&$ action $=$ changePageSize\&pageSize $=25$

Scopus AuthorID: 36907342200

https://www.scopus.com/authid/detail.uri?authorId=36907342200

Google Scholar https://scholar.google.com/citations?user=QfajEEcAAAAJ 